\title{
Resource Use, Availability and Cost in the Provision of Critical Care in Tanzania: A Systematic Review
}

Joseph Kazibwe ( $\sim$ Joseph.Kazibwe@lshtm.ac.uk)

London School of Hygiene and Tropical Medicine https://orcid.org/0000-0002-8315-1503

Hiral A. Shah

Center for Global Development; MRC Centre for Global Infectious Disease Analysis, Department of Infectious Disease Epidemiology, School of Public Health Imperial College London

August Kuwawenaruwa

Ifakara Health Institute

Carl Otto Schell

Karolinska Institute, Department of Global Public Health; Uppsala University Center for Clinical Research

Karima Khalid

Muhimbili University of Health and Allied Sciences Department of Anaesthesia and critical care;

Phuong Bich Tran

University of Antwerp Department of family and population health

Srobana Ghosh

Center for Global Development

Tim Baker

London School of Hygiene and Tropical Medicine Department of Clinical Research; Ifakara health Institute; Muhimbili University of Health and Allied Sciences Department of Emergency Medicine

Lorna Guinness

Center for Global Development

\section{Research}

Keywords: Critical care, Costs of critical care, forms of critical care, Resources, Low- and middle-income countries (LMICs), Tanzania

Posted Date: November 15th, 2021

DOI: https://doi.org/10.21203/rs.3.rs-1062067/v1

License: (c) (i) This work is licensed under a Creative Commons Attribution 4.0 International License. Read Full License 


\section{Abstract}

Introduction

Critical care is essential in saving lives of critically ill patients, however, provision of critical care across lower resource settings can be costly, fragmented and heterogenous. Despite the urgent need to scale-up the provision of critical care, little is known about its availability and cost. Here, we aim to systematically review and identify reported resource use, availability and costs for the provision of critical care and the nature of critical care provision in Tanzania.

Methods

The systematic review followed the Preferred Reporting Items for Systematic Reviews and Meta-Analyses (PRISMA) guidelines; PROSPERO registration number: CRD42020221923. We searched Medline, Embase and global health databases. We included studies that reported on provision of critical care, cost and availability of resources used in the provision of critical care published after 2010. Costs were adjusted and reported in 2019 USD and TZS using the world bank GDP deflators.

Results

A total 31 studies were found to fulfil the inclusion and exclusion criteria. Critical care identified in Tanzania was categorised into: ICU delivered critical care and non-ICU critical care. The availability of ICU delivered critical care was limited to urban settings whereas non-ICU critical care was found in rural and urban settings. 15 studies reported on the costs of services related to critical care yet no study reported an average or unit cost of critical care. Costs of medication, equipment (e.g. oxygen, PPE), services, and human resources were identified as inputs to specific critical care services in Tanzania.

Conclusion

There is limited evidence on the resource use, availability and costs of critical care in Tanzania. There is a strong need for further empirical research on critical care resources availability, utilization and costs across specialties and hospitals of different level in LMICs like Tanzania to inform planning, priority setting and budgeting for critical care services.

\section{Background}

Critical care is an essential element of healthcare whose importance has been highlighted globally during the COVID-19 pandemic with countries experiencing overwhelming numbers of critically ill patients ${ }^{1-3}$. As a result, the care of critical illness has become an urgent point of focus in global health policy.

Critical care entails the care given to a patient in need of enhanced monitoring, treatment and attention, due to a life-threatening illness or injury ${ }^{4}$. There have been great advances in the provision of critical care for example invasive and non-invasive monitoring techniques, mechanical ventilation (MV), and renal replacement therapy, among others, resulting in reduced mortality rates in patients with critical illness, especially in high income countries ${ }^{5}$.

However, such critical care is provided in sophisticated intensive care units using equipment which are costly to procure and maintain 6 . This makes it difficult for low resource settings to acquire such equipment to meet the needs of their populations and has led to recommendations for the development of more affordable critical care models that can be provided in any hospital settings and to all critically ill patients ${ }^{1,7,8}$. Moreover, most critically ill patients do not need critical care at ICU-level ${ }^{9}$ and large unmet needs of even basic lifesaving critical care have been found in LMICs ${ }^{10-12}$. With various national and international stakeholders calling for critical care scale-up ${ }^{13}$, it is necessary to understand the resources needed in the provision of critical care and their respective costs. Unfortunately, knowledge on the current availability of resources and the costs of critical care remains sparse ${ }^{1,14,15}$. There is no systematic review that examines the available resources, utilisation and costs of critical care generally ${ }^{16}$ nor in low and middle income country settings.

To inform the planning and scale up of critical care provision in a low-income country setting, this study takes a case study approach to review available knowledge on the current resource availability, utilisation and cost in the provision of critical care in Tanzania ${ }^{16}$.

\section{Methods}

The systematic review followed the Preferred Reporting Items for Systematic Reviews and Meta-Analyses (PRISMA) guidelines ${ }^{17}$ and the protocol was registered with PROSPERO; registration number: CRD42020221923 ${ }^{16}$. The full methodological protocol used in this review is available elsewhere ${ }^{16}$

\section{Search strategy and selection process}

Following PRISMA guidelines, 3 electronic databases (i.e. Medline, Embase and Global Health) were systematically searched for articles published since $2010^{18}$. A ten-year time frame was considered to ensure that findings reflect the present-day resource utilization paradigm as resources used and their costs vary as technology and clinical guidelines evolve. Bibliographies of included articles were reviewed to find relevant articles that fulfil the inclusion criteria but had not been identified. Google and Google Scholar were also used to search for published articles that may not have been indexed within the 
databases. As internet search engines typically return several thousand results, the searches were restricted to the first fifty hits and links to potentially relevant material were accessed $^{19}$.

The PICO framework (Table 1) describes major components used to identify key words. Other concepts and search terms are listed in the supplementary material. Key words included critical care, critical illness, resource use and setting. Some diseases where also added to the research string (for example neonatal disorders, HIV, Malaria and $\mathrm{TB}^{20}$ ), on the premise that these are conditions that have a high risk of critical illness. See supplementary 1 for detailed key words. Rayyan QCRI software was used to identify and remove duplicates ${ }^{21}$ and screen articles by title and abstract through a double-review process.

\section{Eligibility criteria}

A study was considered eligible if it was published in English and reported on the provision of critical care ${ }^{22}$, services offered under critical care, resources and or costs incurred by the health system or health providers in providing critical care in Tanzania. A detailed inclusion/ exclusion criterion can be found in supplementary 2.

\section{Data extraction and synthesis}

A bespoke data extraction form was developed and used to record extracted data. The extracted data included author, year of publication, context (location, setting- urban or rural, type of facility, level of facility), critical care services offered, critical care equipment available, costing perspective, costing year, currency used, type of provider, payer, source of cost data, costing time frame, direct medical costs, resources used.

A narrative synthesis of extracted data was conducted to report an overview of study characteristics of the eligible studies. We described the characteristics of critical care provision as identified in the literature and resources available for the provision of critical care in Tanzania. In addition, quantitative and qualitative syntheses were performed for cost and resource use data. Costs and resources used were categorized into groups based on a standard input-wise categorisation, for example, human resources, diagnostics, services, consumables and medication. Costs were first standardized by adjusting for inflation using the GDP deflators for Tanzania ${ }^{23}$ and reported in USD and TZS of 2019 value.

\section{Risk of bias in individual studies}

The quality of the included articles was assessed using an adaptation of the Reference Case for Estimating the Costs of Global Health Services and Interventions ${ }^{24}$, which provides a framework for quality assessment and data extraction. Furthermore, methodological quality of studies that reported costs were further assessed by an appraisal checklist by Adawiyah et $\mathrm{al}^{25}$. Any discrepancies were addressed by a joint re-evaluation of the article among all authors.

\section{Results}

\section{Study characteristics}

Thirty-one studies fulfilled the inclusion criteria, of which 14 reported on the costs associated with critical care in Tanzania (Table 2). The disease areas covered by eligible studies included; oncology $(n=1)$, trauma $(n=4)$, obstetrics $(n=3)$, neonatal/child care $(n=2), \operatorname{HIV}(n=1)$, renal failure $(n=1)$, TB $(n=1)$, malaria $(n=3)$, stroke $(n=1)$ and typhoid $(n=1)$, antimicrobial resistance $(n=1)$ surgery $(n=2)$ respiratory illness $(n=1)$, blood transfusion $(n=1)$, no disease or area specific $(n=8)$. The majority of studies were cross sectional in design $(n=20)$ and qualitatively reported on the location of critical care and critical care services available.

Most studies were conducted in a specific region: the Coast Zone $(n=7)$, Lake Zone $(n=3)$, Northern Highland Zone $(n=3)$ and Southern Highland Zone $(n$ $=3$ ) and Central Zone $(n=1)$. A zone is a geographical area made up of health regions which are made up of districts. Seven studies were nationally representative $(n=7)$; two studies didn't specify a given region. Three studies were carried out in rural settings while the rest were urban or mixed settings. Nine studies specified that they were conducted in in public (government owned) facilities and six specified non-governmental organisations including faith/missionary based hospitals.

\section{Critical care provision in Tanzania}

The structure of the health system in Tanzania comprises six levels ${ }^{26}$ starting with the village health post (lowest level), dispensaries, health centres, district hospitals, regional hospitals and tertiary referral hospitals (the highest level) ${ }^{26-39}$. Critical care is usually offered at the hospital level only, that is the district hospital, regional hospitals and referral hospitals $26-31,33-40$. In addition, Nicks et al state that district hospitals offer basic forms of critical care while referral hospitals offer critical care in ICUs ${ }^{26}$. Thirteen of the fifteen studies that reported on critical care provision were carried out in urban settings. Two of the fifteen studies were carried out in both rural and urban settings; no study was exclusively carried out in a rural setting. Based on the literature, we further categorise critical care into "ICU delivered critical care" (otherwise known as ICU based critical care) and "non-ICU based critical care".

Seven studies reported on ICU delivered critical care offered in tertiary referral hospitals in Tanzania $28,29,35,36,38,39$ including regional hospitals. For example, Murthy et al state that St. Francis Hospital in Ifakara region had 10 ICU beds and Sekou Toure Regional Referral Hospital in Mwanza had 8 ICU beds ${ }^{33}$. ICU delivered critical care services included intubation and ventilation. For example, one study found that $54.2 \%$ of all ICU patients were intubated or 
ventilated $^{38}$. In addition, two studies reported surgical interventions that were conducted on patients cared for in ICU included wound debridement, treatment of fractures, craniotomy, underwater seal drainage, tracheostomy, eye surgery and Thoracotomy ${ }^{38,41}$. The district hospitals, for which studies were available did not provide ICU delivered critical care ${ }^{34}$.

Critical care outside the ICU was reported to be delivered either in operating theatres or in emergency units and general wards. For example, operating theatres at Kilimanjaro Christian Medical Centre (KCMC) offered critical care for cases like trauma and sepsis ${ }^{42}$. Theatres in lower-level hospitals like district hospitals often offer initial critical care before referring the patient to higher level hospitals that can offer ICU based critical care. Although district hospitals and some regional hospitals were reported not to have ICUs, these facilities were reported to offer critical care in the general wards ${ }^{34}$. Some hospitals without ICUs designated areas within general wards to cater for the critically ill patients ${ }^{34}$. Furthermore, Staton et al found that some critical care services including intubation were performed in the emergency units ${ }^{39}$.

\section{Availability of resources required for critical care}

The majority of eligible studies reported on the known resources used for critical care $(n=21)$. However, many studies did not report the extent to which the resources were readily available at a given hospital $(n=18)$. Three studies reported on availability and use of critical care resources and indicate that their availability varies between hospitals and is sometimes unreliable or inconsistent (supplementary 3 ). Two studies find that there is a scarcity of trained staff in critical care ${ }^{34,37}$. Further, the availability of critical care equipment was heterogenous with scarcity in the areas of mask and tubing, pulse oximetry, oxygen cylinders, adult and paediatric oropharyngeal airway and PPE eye protection highlighted. In addition, a greater scarcity in paediatric than adult critical care equipment was identified ${ }^{34,37}$.

\section{Resource use and cost of resources associated with provision of critical care}

Of the 31 studies, 14 reported on the resource use and critical care costs and were appraised for quality using the Adawiyah et al adapted appraisal checklist $^{25}$ (Supplementary 4). All 14 studies were found to have clear research questions, mentioned the specific costing perspective, included relevant inputs, clearly stated methods for quantifying resources and reported costs. Four studies did not specify the time horizon while four studies partially addressed it. The majority of the studies $(n=8)$ carried out some form of sensitivity analysis. All studies that collected primary data stated sample size but did not mention how it was determined and whether it was sufficient.

Published costs of critical care were reported as economic costs $(n=8)$ or financial costs $(n=6)$, using a mix of bottom up $(n=9)$ and top down $(n=5)$ approaches. Sources of the costs were local data collected from hospital records, surveys and price lists. Surveys (including key informant interviews) were a common method of data collection $(n=9)$. Three studies used patient level data on resource use to inform costs (Kimaro ${ }^{43}$; Sicuri ${ }^{44}$; Riewpaiboon ${ }^{45}$ ). Hospital or laboratory records were used in 6 of the 14 studies. Some studies used both survey and records review as the source of data ( $n=6$ ). Two studies used international literature as a source of data $(n=2)$. Unit costs reported included cost per program, cost per patient, cost per visit, cost per patient day, cost per episode, cost per bed day, inpatient cost, total annual cost, cost per case (see table 4).

Although many studies reported costs within differing disease specific (e.g. malaria and anaemia) or general hospital services (e.g. inpatient and outpatient care), no study identified the cost of elements that are specific for the treatment of critical illness. The highest reported average cost per patient was for a patient undergoing caesarean section (USD 471.28) ${ }^{46}$. The lowest reported cost per patient was for hospitalisation for stroke in a rural area (USD 12.76) ${ }^{47}$. A nationally representative study of general hospital services including critical care found that unit costs vary by provider ownership (public, $\mathrm{NGO}$ and private) and level of health facility ${ }^{48}$ (regional vs primary care). Services provided at private hospitals were more expensive than the same services received at public hospitals. NGO hospitals were less expensive than public hospitals.

When looking at cost categories, 2 studies reported costs of equipment, 2 studies reported costs of consumables and 6 studies reported medication cost. Within studies, we found per item cost for equipment (4 items), consumables ( 3 items) and medication (13 items). The cost of a mannequin used in training was the most expensive piece of equipment reported (USD 76.03) ${ }^{49}$. In the medication category, tranexamic acid was the most expensive per dose $\left(\text { USD 9.74) }{ }^{50} \text {, whereas antimicrobials were the most expensive on a per case basis (USD 30.36 }\right)^{51}$.

While diagnostics are not part of critical care provision, they form part of the overall patient care and can inform future economic evaluations. Six studies reported on the cost of diagnostics, for example, FBC, serum cryptococcal meningitis test, sputum culture and imaging (see supplementary material).

Three studies reported human resource costs (see table 6). No human resource costs were identified as specifically for ICU or non-ICU critical care. Reporting of human resource cost was heterogenous. One study provided monthly salaries for all personnel with monthly salaries ranging from USD 2721.79 for medical specialists USD 313.34 for nurses ${ }^{52}$. Another study reported total cost of personnel as a line item. The third study reported unit costs (i.e. cost per patient) treatment for all obstetric complications broken down by staff category. This study found that the most important cost was for an enrolled nurse or midwife (USD 43.62 per patient) and that the lowest unit personnel cost was for an anaesthesiologist (less than 0.01 USD per patient) ${ }^{53}$.

\section{Discussion}

Our review found limited evidence on resource use, availability and costs of critical care in Tanzania. Of the eligible evidence, we found high variability in the geographical distribution and availability of resources needed for both ICU and non-ICU critical care provision. We found that ICU critical care was provided at the tertiary level in urban areas and no published provision in rural areas, whereas, non-ICU critical care was evident in both rural and urban 
areas. Within hospitals, we find that availability of key critical care resources (e.g. pulse oximeters, oxygen cylinders, mask and tubing) can be limited but the use of these resources is not documented. We, finally, find no reported estimates on the unit costs of critical care; and that the generation and reporting of cost data is not standardised thereby limiting synthesis or aggregation.

\section{Availability of critical care in Tanzania}

The majority of ICUs identified in our systematic review were located in tertiary referral hospitals and private hospitals located in urban areas (Dar es Salaam, Moshi, Mwanza, Mbeya city). This is of particular concern in Tanzania where the majority of the population (64.77) lives in rural areas ${ }^{54}$. Although this inequity in service distribution is not unique to Tanzania as previous studies in LMICs found all hospitals with ICUs were located in cities ${ }^{33}$, it is further exacerbated by a lack of critical care guidelines that cater to rural areas ${ }^{55}$. Such geographical inequity in ICU critical care could be detrimental and of particular concern during a critical care crisis (e.g. COVID-19) ${ }^{1}$.

However, critical care delivery is heterogenous and can be provided in advanced or basic forms, depending on resource availability. Critical care can involve high tech and high-cost equipment that requires highly trained staff (e.g. mechanical ventilation) and is more often found in the ICU. Investing in this level of critical care is therefore an expensive policy decision and may explain the lack of ICU critical care availability in rural areas in Tanzania. On the other hand, investing in adequately resourced critical care outside of ICUs can potentially save lives and reduce the case load that requires ICU care ${ }^{56}$. We found that non-ICU critical care was reported to be given in wards and theatres ${ }^{39}$ across rural and urban areas.

A key finding of the literature review was that neither the level of care provided, complexity, resource intensity or quality of provision was reported. We were therefore unable to characterise critical care in Tanzania other than by where it is delivered i.e. ICU vs non-ICU based critical care. This is of concern as care for the critically ill takes many forms and is not necessarily synonymous with ICU care. Critical care, at least in its more basic forms, should be readily available to all patients in need in any hospital. Characterising the minimum needs for the care of a critically ill patient will facilitate our understanding of what elements of critical care are currently available as well as recommendations for the progressive improvement of critical care in all facilities. Previous research suggests that basic critical care, which effectively identifies and treats all critically ill patients, should be available and provided in all settings within a hospital (e.g. in wards) across rural and urban settings ${ }^{57,58}$. Recently, some of this paper's authors have proposed the concept of Essential Emergency and Critical Care (EECC) across LMICs. EECC is pragmatic and low-cost care of critical illness that does not need to be reliant on sophisticated technology, and have a primary focus on simple, effective actions that have large potential impact on the population ${ }^{56}$ and the components of have been specified in a large global consensus ${ }^{8}$.

Given the lack of availability and access of critical care across Tanzania, such novel approaches may provide a building block to developing a fully resourced, equitable critical care system ${ }^{59}$. However, decision makers require further evidence on the optimal design, costs, budget impact and costeffectiveness of such critical care interventions in rural and urban systems.

\section{Complexity of resources within critical care}

At the hospital level, we found that many studies identified resources that were used in the provision of services that included a critical care component but a few studies went further to report on the availability of the resources at the facility (e.g. equipment, consumables and human resources). For example, while oxygen is one of the essential resources required in the provision of critical care, many hospitals still lack basic equipment for its storage and delivery ${ }^{60}$. Our findings show that even when oxygen is available, the equipment and consumables required to facilitate provision of oxygen therapy can be missing ${ }^{39,61}$. This leaves a considerable proportion of critically ill patients in need of medical oxygen without the necessary treatment, incurring unnecessary deaths and disability.

Many reasons exist as to why availability and supply of oxygen is limited in settings such as Tanzania. For example, supply and scaling of medical oxygen is a complex process and is often controlled though monopoly suppliers. Regulation and high investment costs create barriers for new firms to enter the market and easily scale up supply. In Tanzania, medical oxygen supply is controlled centrally by a quasi-governmental monopoly organisation ${ }^{62}$. On the demand side, there is limited funding for medical oxygen with procurement decentralised to individual hospitals with constraint budgets ${ }^{60}$. Alternatives, such as oxygen concentrators and hospital plants for the local production of oxygen, are affected by the need for a constant supply of electricity, compounded by challenges with maintaining equipment. In Tanzania, approx. $50 \%$ of hospitals are without a constant oxygen supply ${ }^{37}$ and there is limited local capacity to maintain and repair oxygen concentrators like Tanzania.

In addition to oxygen equipment, we found variability in availability of PPE and human resources across studies. While some personal protective equipment (PPE), especially gloves, were available in most hospitals, others, such as eye protection, remained unavailable, which is in line with previous research ${ }^{63}$. In terms of human resources, evidence suggests that only $20 \%$ of hospitals have at least one health worker trained in adult critical care which includes administering complex oxygen related equipment ${ }^{34,55,57}$. Technical assistance, training of health workers, and improved processes for non ICU based care, development of context-specific critical care guidelines, building capacity in equipment maintenance and biomedical engineering in facilities, and support to medical oxygen infrastructure development should be prioritised in applications to multilaterals and technical assistance agencies ${ }^{34,64,65}$.

\section{Costs of critical care}

Costing of critical care is vital in eliciting potential budget constraints or impacts, assessing cost-effectiveness, providing insight into the economic burden of disease and can be useful for understanding the resources incurred by health systems, other payers, and patients. We find that no study reported or 
calculated an average cost or cost per patient day for the provision of critical services. On the other hand, many studies reported individual costs of resources associated with provision of critical care and it was possible to identify the cost of specific resources needed in critical care provision (i.e. human resource cost, services, medication, and other consumables). Such limited evidence could be due to no formal or standardised definition of critical care existing thereby reducing specificity when costing critical care provisioning. Another possibility may be that patients who require critical care are heterogenous. The underlying demographics, epidemiology, risk factors, patient pathway and interventions administered are also heterogenous thereby making aggregation and estimates of average cost challenging. This is further confirmed by the data extracted in this review which showed that reporting of costs within eligible studies were inconsistent thereby making comparisons or synthesising information across studies difficult. There is an urgent need to understand the resources required and their cost implications to inform the planning of improved critical care, globally.

\section{Limitations}

There are a number of inherent limitations with this systematic review. Firstly, we tailored our search strategy to account for the lack of standardised or formal definitions for critical illness, critical care provision and ICUs ${ }^{57}$ by including specific terms for conditions likely to lead to critical illness and identified in consultation with clinicians on the authorship team. Here, we may have introduced a personal bias by focussing on specific conditions and excluding others. Secondly, cost and resource use in an African context are traditionally poorly documented and can fluctuate due to market dynamics and resource availability. While this systematic review provides key insights into peer reviewed published information on the resource use, availability and costs of critical care in Tanzania, researchers must update a previous nationally representative facility survey conducted in 2012 extending it to include an understanding of the costs of critical care provision that includes patient level data on resource use. Finally, we opted to only include articles in English but believe the extent and effects of language bias are diminished recently because of the shift towards publication of studies in English ${ }^{66}$.

\section{Conclusion}

Critical care is essential in the prevention of mortality among critically ill patients, yet limited evidence exists on the costs and cost-effectiveness of scaling up critical care thereby hindering informed planning for investments in key life-saving interventions. We further find that ICU based critical care provision is currently only provided in urban areas in Tanzania and there is an urgent need to assess the quality of non-ICU based critical care implemented to address the gap in critical care provision in rural and urban areas. Evidence on resources used and potential costs in critical care is limited, and, along with a specific focus on oxygen supply and delivery which is a key resource in critical care, requires further research. Improving the evidence base on the costs, utilisation, cost-effectiveness and equity impacts of different strategies for critical care services across rural and urban areas is needed to help prevent unnecessary deaths caused by critical illness in Tanzania.

\section{Declarations}

\section{Ethical Approval and Consent to participate}

This study is a review of secondary data, it is exempt from application for ethical review.

\section{Consent for publication}

All authors have consented to this publication

\section{Availability of supporting data}

Not applicable

\section{Competing interests}

Authors declare no competing interests and the funders did not in any way influence the development of the development of this study.

\section{Funding statement}

This work was supported by the Wellcome Trust [221571/Z/20/Z], as part of the 'Innovation in low-and middle-income countries' Flagship. JK's time was funded by the Bill and Melinda Gates Foundation through the iDSI Plus grant, grant number: INV-006987

\section{Authors' contributions}

Below is the detailed breakdown of their contribution.

Concept and design: JK, HS, LG, AJ, PT, OS, TB

Development of first draft: JK, HS, LG

Acquisition of data: JK, HS, LG, PT, SG

Analysis and interpretation of data: JK, HS, LG, PT, SG, OS

Drafting of the manuscript: JK, HS, LG 
Critical revision of paper for important intellectual content: TB, OS, LG, KK, AJ

Statistical analysis: -

Provision of study materials:

Obtaining funding: TB, OS

Administrative and technical support:

Supervision: LG, HS

\section{Acknowledgements}

Not applicable

\section{References}

1. Baker T, Otto Schell C, Brun Petersen D, et al. Essential care of critical illness must not be forgotten in the COVID-19 pandemic. Lancet. 2020;395:12531254. doi:10.1016/S0140-6736(20)30793-5

2. Barasa E, Kairu A, Nganga W, et al. Examining Unit Costs for COVID-19 Case Management in Kenya. medRxiv. Published online October 13, 2020:2020.10.08.20209684. doi:10.1101/2020.10.08.20209684

3. Sen-Crowe B, Sutherland M, McKenney M, Elkbuli A. A Closer Look Into Global Hospital Beds Capacity and Resource Shortages During the COVID-19 Pandemic. J Surg Res. 2021;260:56. doi:10.1016/J.JSS.2020.11.062

4. National Institute for Health and Care Excellence (NICE). What "critical care" means | Information for the public | Rehabilitation after critical illness in adults | Guidance | NICE. Published March 25, 2009. Accessed November 1, 2020. https://www.nice.org.uk/guidance/cg83/ifp/chapter/What-criticalcare-means

5. Zimmerman JE, Kramer AA, Knaus WA. Changes in hospital mortality for United States intensive care unit admissions from 1988 to 2012 . Crit Care. 2013;17(2):R81. doi:10.1186/cc12695

6. Turner HC, Van Hao N, Yacoub S, et al. Achieving affordable critical care in low-income and middle-income countries Commentary Handling editor Seye Abimbola. BMJ Glob Heal. 2019;4:1675. doi:10.1136/bmjgh-2019-001675

7. Schell CO, Gerdin Wärnberg M, Hvarfner A, et al. The global need for essential emergency and critical care. Crit Care. 2018;22(1):1-5. doi:10.1186/s13054-018-2219-2

8. Schell CO, Khalid K, Wharton-Smith A, et al. Essential Emergency and Critical Care: a consensus among global clinical experts. BMJ Glob Heal. 2021;6(9):e006585. doi:10.1136/BMJGH-2021-006585

9. Kayambankadzanja RK, Schell CO, Namboya F, et al. The prevalence and outcomes of sepsis in adult patients in two hospitals in Malawi. Am J Trop Med Hyg. 2020;102(4):896-901. doi:10.4269/ajtmh.19-0320

10. Kayambankadzanja RK, Schell CO, Mbingwani I, Mndolo SK, Castegren M, Baker T. Unmet need of essential treatments for critical illness in Malawi. Chen T-H, ed. PLoS One. 2021;16(9):e0256361. doi:10.1371/JOURNAL.PONE.0256361

11. King C, Banda M, Bar-Zeev N, et al. Care-seeking patterns amongst suspected paediatric pneumonia deaths in rural Malawi. Gates Open Res 2021 4178. 2021;4:178. doi:10.12688/gatesopenres.13208.2

12. H. C, T. P, P. K, A.M. M, G. S, D. M. A survey of emergency and surgical services in the United Republic of Tanzania. Acad Emerg Med. 2011;18(5 SUPPL. 1):S242. doi:http://dx.doi.org/10.1111/j.1553-2712.2011.01073.x

13. World Health Organisation. Strengthening the Health Systems Response to COVID-19: Creating Surge Capacity for Acute and Intensive Care .; 2020. Accessed September 21, 2021. http://apps.who.int/bookorders.

14. World Bank. World Bank facilitates immediate support and resources for the COVID-19 (Coronavirus) emergency in Bolivia. Published April 2, 2020. Accessed December 16, 2020. https://www.worldbank.org/en/news/press-release/2020/04/02/el-banco-mundial-facilita-apoyo-y-recursosinmediatos-para-atender-la-emergencia-por-el-covid-19-coronavirus-en-bolivia

15. The World Bank. The World Bank Annual Report 2020: Supporting Countries in Unprecedented Time.; 2020. Accessed December 16, 2020. https://www.worldbank.org/en/about/annual-report/covid-response

16. Kazibwe J, Shah HA, Kuwawenaruwa A, et al. Resource availability, utilisation and cost in the provision of critical care in Tanzania: a protocol for a systematic review. BMJ Open. 2021;11(8):e050881. doi:10.1136/BMJOPEN-2021-050881

17. Shamseer L, Moher D, Clarke M, et al. Preferred reporting items for systematic review and meta-analysis protocols (prisma-p) 2015: Elaboration and explanation. BMJ. 2015;349(January):1-25. doi:10.1136/bmj.g7647

18. Moher D, Liberati A, Tetzlaff $J$, et al. Preferred reporting items for systematic reviews and meta-analyses: The PRISMA statement (Chinese edition). $J$ Chinese Integr Med. 2009;7(9):889-896. doi:10.3736/jcim20090918

19. Savilaakso S, Garcia C, Garcia-Ulloa J, et al. Systematic review of effects on biodiversity from oil palm production. Environ Evid. 2014;3(1):4. doi:10.1186/2047-2382-3-4

Page 7/17 
20. Abbafati C, Machado DB, Cislaghi B, et al. Global burden of 369 diseases and injuries in 204 countries and territories, 1990-2019: a systematic analysis for the Global Burden of Disease Study 2019. Lancet. 2020;396(10258):1204-1222. doi:10.1016/S0140-6736(20)30925-9

21. Ouzzani M, Hammady H, Fedorowicz Z, Elmagarmid A. Rayyan-a web and mobile app for systematic reviews. Syst Rev. 2016;5(1). doi:10.1186/s13643-016-0384-4

22. Kazibwe J, Shah HA, Kuwawenaruwa A, et al. Resource availability, utilization and cost in the provision of critical care in Tanzania: A protocol for a systematic review. BMJ Open. Published online 2021.

23. World bank. GDP deflator (base year varies by country) - Tanzania . Accessed June 2, 2021. https://data.worldbank.org/indicator/NY.GDP.DEFL.ZS? locations $=\mathrm{TZ}$

24. Vassall A, Sweeney S, Kahn JG, et al. Reference Case for Estimating the Costs of Global Health Services and Interventions.

25. Adawiyah R al, Saweri OPM, Boettiger DC, et al. The costs of scaling up HIV and syphilis testing in low- and middle-income countries: a systematic review. Health Policy Plan. 2021;2021:1-16. doi:10.1093/heapol/czab030

26. Nicks BA, Sawe HR, Juma AM, Reynolds TA. The state of emergency medicine in the United Republic of Tanzania. African J Emerg Med. 2012;2(3):97102. doi:10.1016/j.afjem.2012.06.002

27. Sylvanus E, Sawe HR, Muhanuzi B, et al. Profile and outcome of patients with emergency complications of renal failure presenting to an urban emergency department of a tertiary hospital in Tanzania. BMC Emerg Med. 2019;19(1):11. doi:http://dx.doi.org/10.1186/s12873-019-0229-2

28. Engdahl Mtango S, Lugazia E, Baker U, Johansson Y, Baker T. Referral and admission to intensive care: A qualitative study of doctors' practices in a Tanzanian university hospital. Brenner S, ed. PLoS One. 2019;14(10):e0224355. doi:10.1371/journal.pone.0224355

29. Mkoka DA, Goicolea I, Kiwara A, Mwangu M, Hurtig AK. Availability of drugs and medical supplies for emergency obstetric care: Experience of health facility managers in a rural District of Tanzania. BMC Pregnancy Childbirth. 2014;14(1):1-10. doi:10.1186/1471-2393-14-108

30. Papali A, Adhikari NKJ, Diaz J V., et al. Infrastructure and organization of adult intensive care units in resource-limited settings. In: Sepsis Management in Resource-Limited Settings. Springer International Publishing; 2019:31-68. doi:10.1007/978-3-030-03143-5_3

31. Mwiga F, Monaghan M. Development of a difficulty airway trolley (DAT) at a tertiary referral hospital in northern Tanzania. Trends Anaesth Crit Care. 2020;30:e107-e108. doi:http://dx.doi.org/10.1016/j.tacc.2019.12.265

32. Sawe HR, Reynolds TA, Mfinanga JA, et al. The clinical presentation, utilization, and outcome of individuals with sickle cell anaemia presenting to urban emergency department of a tertiary hospital in Tanzania. BMC Hematol. 2018;18(1):25. doi:http://dx.doi.org/10.1186/s12878-018-0122-3

33. Murthy S, Leligdowicz A, Adhikari NKJ. Intensive care unit capacity in low-income countries: A systematic review. PLoS One. 2015;10(1):116949. doi:http://dx.doi.org/10.1371/journal.pone.0116949

34. Baker T, Lugazia E, Eriksen J, Mwafongo V, Irestedt L, Konrad D. Emergency and critical care services in Tanzania: A survey of ten hospitals. BMC Health Serv Res. 2013;13(1):1-9. doi:10.1186/1472-6963-13-140

35. Rajaguru PP, Jusabani MA, Massawe H, Temu R, Sheth NP. Understanding surgical care delivery in Sub-Saharan Africa: a cross-sectional analysis of surgical volume, operations, and financing at a tertiary referral hospital in rural Tanzania. Glob Heal Res policy. 2019;4:30.

doi:https://dx.doi.org/10.1186/s41256-019-0122-2

36. Reynolds TA, Mfinanga JA, Sawe HR, Runyon MR, Mwafongo V. Emergency care capacity in Africa: a clinical and educational initiative in Tanzania. J Public Health Policy. 2012;33(Supplement 1):S126-S137. doi:http://dx.doi.org/10.1057/jphp.2012.41

37. Penoyar T, Cohen $\mathrm{H}$, Kibatala P, et al. Emergency and surgery services of primary hospitals in the United Republic of Tanzania. BMJ Open. 2012;2(1):e000369. doi:10.1136/bmjopen-2011-000369

38. Chalya PL, Gilyoma JM, Dass RM, et al. Trauma admissions to the Intensive care unit at a reference hospital in Northwestern Tanzania. Scand J Trauma Resusc Emerg Med. 2011;19:61. doi:10.1186/1757-7241-19-61

39. Staton CA, Msilanga D, Kiwango G, et al. A prospective registry evaluating the epidemiology and clinical care of traumatic brain injury patients presenting to a regional referral hospital in Moshi, Tanzania: challenges and the way forward. Int J Inj Contr Saf Promot. 2017;24(1):69-77. doi:10.1080/17457300.2015.1061562

40. Sawe HR, Reynolds TA, Mfinanga JA, et al. The clinical presentation, resource utilization, and outcomes of patients with sickle cell disease presenting to the ED of the muhimbili national Hospital in Dar es Salaam Tanzania. Acad Emerg Med. 2016;23(SUPPL. 1):S99. doi:http://dx.doi.org/10.1111/acem.12974

41. Mwandri M, Hardcastle TC, Sawe H, et al. Trauma burden, patient demographics and care-process in major hospitals in Tanzania: A needs assessment for improving healthcare resource management. African J Emerg Med. 2020;10(3):111-117. doi:http://dx.doi.org/10.1016/j.afjem.2020.01.010

42. Rajaguru PP, Jusabani MA, Massawe H, Temu R, Sheth NP. Understanding surgical care delivery in Sub-Saharan Africa: a cross-sectional analysis of surgical volume, operations, and financing at a tertiary referral hospital in rural Tanzania. Glob Heal Res Policy. 2019;4(1):30. doi:10.1186/s41256019-0122-2

43. Kimaro GD, Mfinanga S, Simms V, et al. The costs of providing antiretroviral therapy services to HIV-infected individuals presenting with advanced HIV disease at public health centres in Dar es Salaam, Tanzania: Findings from a randomised trial evaluating different health care strategies. PLoS One. 2017;12(2):e0171917. doi:http://dx.doi.org/10.1371/journal.pone.0171917

44. Sicuri E, Vieta A, Lindner L, Constenla D, Sauboin C. Economic costs of malaria in children in three Sub-Saharancountries: Ghana, Tanzania and Kenya. Trop Med Int Heal. 2011;16(SUPPL. 1):117. http://ovidsp.ovid.com/ovidweb.cgi?T=JS\&PAGE=reference\&D=emed12\&NEWS=N\&AN=70589204 
45. Riewpaiboon A, Piatti M, Ley B, et al. Cost of illness due to typhoid fever in Pemba, Zanzibar, East Africa. J Heal Popul Nutr. 2014;32(3):377-385. http://www.jhpn.net/index.php/jhpn/article/view/2819/1043

46. Mengistu T, Berruti A, Krivelyova A, Swor M, Waite R, Maro G. Cost of providing emergency obstetric care in Tanzania's Kigoma region. Int J Health Plann Manage. 2019;34(4):e1510-e1519. doi:http://dx.doi.org/10.1002/hpm.2820

47. Kabadi GS, Walker R, Donaldson C, Shackley P. The cost of treating stroke in urban and rural Tanzania: A 6-month pilot study. African J Neurol Sci. 2013;32(2). http://ajns.paans.org/article.php3?id_article=446

48. James C, Bura M, Ensor T. The costs of delivering health services in Tanzania. Findings from a comprehensive costing analysis.

49. Chaudhury S, Arlington L, Brenan S, et al. Cost analysis of large-scale implementation of the "Helping Babies Breathe" newborn resuscitation-training program in Tanzania. BMC Health Serv Res. 2016;16(1):681. http://ovidsp.ovid.com/ovidweb.cgi?

$T=J S \& P A G E=$ reference\& $D=$ emed $17 \& N E W S=N \& A N=618644170$

50. Guerriero C, Cairns J, Jayaraman S, Roberts I, Perel P, Shakur H. Giving tranexamic acid to reduce surgical bleeding in sub-Saharan Africa: An economic evaluation. Cost Eff Resour Alloc. 2010;8:1. doi:http://dx.doi.org/10.1186/1478-7547-8-1

51. Penno EC, Baird SJ, Crump JA. Cost effectiveness of surveillance for bloodstream infections for sepsis management in low resource settings. Am $J$ Trop Med Hyg. 2015;93(4):850-860. http://www.ajtmh.org/content/91/5_Suppl_1/74.full.pdf+html

52. Shayo GA, Chitama D, Moshiro C, Aboud S, Bakari M, Mugusi F. Cost-Effectiveness of isoniazid preventive therapy among HIV-infected patients clinicaly screened for latent tuberculosis infection in Dar es Salaam, Tanzania: A prospective Cohort study. BMC Public Health. 2017;18(1):35. doi:http://dx.doi.org/10.1186/s12889-017-4597-9

53. Baynes C, Yegon E, Kimaro G, Lusiola G, Kahwa J. The unit and scale-up cost of postabortion care in Tanzania. Spec Issue Sav women's lives through Emerg Obstet care Volunt Fam planning. 2019;7(Suppl. 2):S327-S341. doi:http://dx.doi.org/10.9745/GHSP-D-19-00035

54. The World Bank Group. Rural population (\% of total population) - Tanzania | Data. 2021. Accessed July 14, 2021. https://data.worldbank.org/indicator/SP.RUR.TOTL.ZS?locations=TZ

55. Schultz MJ, Dunser MW, Dondorp AM, et al. Current challenges in the management of sepsis in ICUs in resource-poor settings and suggestions for the future. Intensive Care Med. 2017;43:612-624. doi:10.1007/s00134-017-4750-z

56. Ranjit S, Kissoon N. Challenges and Solutions in translating sepsis guidelines into practice in resource-limited settings. Trans/ Paediatr. Published online 2021. Accessed August 10, 2021. https://tp.amegroups.com/article/viewFile/66320/pdf

57. Baker T, Khalid K, Acicbe O, McGloughlin S, Amin P. Critical care of tropical disease in low income countries: Report from the Task Force on Tropical Diseases by the World Federation of Societies of Intensive and Critical Care Medicine. J Crit Care. 2017;42:351-354. doi:10.1016/J.JCRC.2017.11.028

58. Bion J, Brown C, Gomersall C, Boulanger C, Isherwood P, Schulman D. Society of Critical Care Medicine 50th Anniversary Review Series: Critical Care Education. Crit Care Med. Published online 2021:1241-1253. doi:10.1097/CCM.0000000000005130

59. Kairu A, Were V, Isaaka L, Agweyu A, Aketch S, Barasa E. Modelling the cost-effectiveness of essential and advanced critical care for COVID-19 patients in Kenya. medRxiv. Published online August 24, 2021:2021.08.16.21261894. doi:10.1101/2021.08.16.21261894

60. Kazibwe Joseph, Baker Peter, Baker Tim, et al. We Can Stop Preventable COVID Deaths by Urgently Prioritising Medical Oxygen and Essential Critical Care | Center For Global Development. Center for Global Development. Published February 9, 2021. Accessed August 2, 2021.

https://www.cgdev.org/blog/we-can-stop-preventable-covid-deaths-urgently-prioritising-medical-oxygen-and-essential

61. Zimmerman A, Fox S, Griffin R, et al. An analysis of emergency care delays experienced by traumatic brain injury patients presenting to a regional referral hospital in a low-income country. PLoS One. 2020;15(10 October 2020):e0240528. doi:http://dx.doi.org/10.1371/journal.pone.0240528

62. Tanzania Medicines and Medical Devices Authority. Guidelines for regulating medical gases. Accessed September 16, 2021. https://www.tmda.go.tz/uploads/publications/en1597391138-GUIDELINES FOR MEDICAL GASES - Final (1)-SK.pdf

63. Powell-Jackson T, King JJC, Makungu C, et al. Infection prevention and control compliance in Tanzanian outpatient facilities: a cross-sectional study with implications for the control of COVID-19. Lancet Glob Heal. 2020;8(6):e780-e789. doi:10.1016/S2214-109X(20)30222-9

64. Murthy S, Adhikari NK. ATS REPORTS Global Health Care of the Critically III in Low-Resource Settings. Ann Am Thorac Soc. 2013;10(5):509-513. doi:10.1513/AnnalsATS.201307-2460T

65. Diaz J V., Riviello ED, Papali A, Adhikari NKJ, Ferreira JC. Global critical care: Moving forward in resource-limited settings. Ann Glob Heal. 2019;85(1):34. doi:10.5334/aogh.2413

66. Cochrane Reviews. Cochrane Handbook: 10.2.2.4 Language bias. In: Cochrane. Accessed September 16, 2021. https://handbook-51.cochrane.org/chapter_10/10_2_2_4_language_bias.htm

\section{Tables}

Table 1: PICO (Population, Intervention, Comparator, Outcome) Framework used to inform the search strategy. 


\begin{tabular}{|ll|}
\hline Element & Description \\
\hline Population & Any patient in need of critical care \\
\hline Intervention & Inpatient services that could form part of critical care provision \\
\hline Comparison & No critical care \\
\hline Outcomes & Critical care services available \\
& Cost of the different inputs to critical care provision per patient \\
& Quantity and type of resources used in provision of critical care per patient \\
\hline
\end{tabular}

Table 2: Study Characteristics $(\mathrm{N}=31)$ 


\begin{tabular}{|c|c|c|c|c|c|c|c|c|}
\hline Article & Disease area & Intervention & Study Type & Purpose Type & $\begin{array}{l}\text { Geographical } \\
\text { area covered }\end{array}$ & $\begin{array}{l}\text { Hospital } \\
\text { Type }\end{array}$ & $\begin{array}{l}\text { Facility/hospital } \\
\text { Level }\end{array}$ & $\begin{array}{l}\text { Source of } \\
\text { data }\end{array}$ \\
\hline \multicolumn{9}{|c|}{ Studies reporting on costs } \\
\hline $\begin{array}{l}\text { Baynes et al } \\
2019\end{array}$ & Obstetrics & $\begin{array}{l}\text { Providing care } \\
\text { to women that } \\
\text { have had an } \\
\text { abortion }\end{array}$ & $\begin{array}{l}\text { Cross } \\
\text { sectional }\end{array}$ & Cost Analysis & $\begin{array}{l}\text { Mwanza, } \\
\text { Arusha and } \\
\text { Zanzibar }\end{array}$ & $\begin{array}{l}\text { NGO \& } \\
\text { Public }\end{array}$ & All & $\begin{array}{l}\text { Records and } \\
\text { interviews }\end{array}$ \\
\hline $\begin{array}{l}\text { Chris et al } \\
2013\end{array}$ & General & $\begin{array}{l}\text { Health } \\
\text { services }\end{array}$ & $\begin{array}{l}\text { Cross } \\
\text { sectional }\end{array}$ & Cost Analysis & National & All & All & Survey \\
\hline $\begin{array}{l}\text { Kabadi et al } \\
2013\end{array}$ & Stroke & $\begin{array}{l}\text { Providing } \\
\text { stroke care }\end{array}$ & Longitudinal & Cost Analysis & $\begin{array}{l}\text { Mbeya and } \\
\text { Dar es } \\
\text { Salaam }\end{array}$ & $\begin{array}{l}\text { NGO \& } \\
\text { Public }\end{array}$ & Tertiary referral & $\begin{array}{l}\text { Survey and } \\
\text { project data }\end{array}$ \\
\hline $\begin{array}{l}\text { Mengistu et al } \\
2019\end{array}$ & $\begin{array}{l}\text { Direct } \\
\text { obstetric } \\
\text { complications }\end{array}$ & $\begin{array}{l}\text { Emergency } \\
\text { Obstetric and } \\
\text { Neonatal Care }\end{array}$ & $\begin{array}{l}\text { Cross } \\
\text { sectional }\end{array}$ & Cost Analysis & Kigoma & Public & $\begin{array}{l}\text { Tertiary, district } \\
\text { hospital and } \\
\text { primary care }\end{array}$ & $\begin{array}{l}\text { Programme } \\
\& \text { hospital } \\
\text { data }\end{array}$ \\
\hline $\begin{array}{l}\text { Mosha et al } \\
2010\end{array}$ & Malaria & $\begin{array}{l}\text { Diagnostic } \\
\text { tools and } \\
\text { drugs }\end{array}$ & $\begin{array}{l}\text { Cross } \\
\text { sectional }\end{array}$ & Cost analysis & $\begin{array}{l}\text { Kilimanjaro } \\
\text { region and } \\
\text { Korogwe } \\
\text { District, } \\
\text { Tanga } \\
\text { region }\end{array}$ & Public & $\begin{array}{l}\text { District and } \\
\text { dispensaries }\end{array}$ & Survey \\
\hline $\begin{array}{l}\text { Riewpaiboon } \\
\text { et al } 2014\end{array}$ & Typhoid & $\begin{array}{l}\text { Typhoid } \\
\text { treatment/care }\end{array}$ & Longitudinal & Cost Analysis & $\begin{array}{l}\text { Pemba and } \\
\text { Zanzibar }\end{array}$ & Public & District hospital & $\begin{array}{l}\text { Record } \\
\text { review and } \\
\text { interviews }\end{array}$ \\
\hline $\begin{array}{l}\text { Sicuri et al } \\
2011\end{array}$ & Malaria & $\begin{array}{l}\text { Malaria } \\
\text { treatment/care }\end{array}$ & Longitudinal & Cost Analysis & Not specified & $\begin{array}{l}\text { Not } \\
\text { specified }\end{array}$ & Not specified & Survey \\
\hline $\begin{array}{l}\text { Chaudhury et } \\
\text { al } 2016\end{array}$ & Neonatal care & $\begin{array}{l}\text { Birth } \\
\text { attendants } \\
\text { training on } \\
\text { neonatal } \\
\text { resuscitation }\end{array}$ & $\begin{array}{l}\text { Cross } \\
\text { sectional }\end{array}$ & Cost Analysis & Mbeya & $\begin{array}{l}\text { NGO \& } \\
\text { Public }\end{array}$ & All & Survey \\
\hline $\begin{array}{l}\text { Penno et al } \\
2015\end{array}$ & $\begin{array}{l}\text { Antimicrobial } \\
\text { resistance }\end{array}$ & $\begin{array}{l}\text { Surveillance } \\
\text { for } \\
\text { Bloodstream } \\
\text { Infections for } \\
\text { Sepsis } \\
\text { Management } \\
\text { in low } \\
\text { resource } \\
\text { setting }\end{array}$ & Modelling & $\begin{array}{l}\text { Economic } \\
\text { evaluation }\end{array}$ & $\begin{array}{l}\text { Northern } \\
\text { Tanzania }\end{array}$ & $\begin{array}{l}\text { Not } \\
\text { specified }\end{array}$ & Not specified & $\begin{array}{l}\text { Laboratory } \\
\text { records }\end{array}$ \\
\hline $\begin{array}{l}\text { Githang'a et } \\
2020\end{array}$ & Oncology & $\begin{array}{l}\text { Oncology } \\
\text { treatment: e.g. } \\
\text { chemotherapy, } \\
\text { off site } \\
\text { radiotherapy, } \\
\text { surgery }\end{array}$ & $\begin{array}{l}\text { Cross- } \\
\text { sectional }\end{array}$ & $\begin{array}{l}\text { Economic } \\
\text { evaluation }\end{array}$ & Mwanza & NGO & Tertiary referral & $\begin{array}{l}\text { Hospital data } \\
\text { \& interviews }\end{array}$ \\
\hline $\begin{array}{l}\text { Guerriero et al } \\
2010\end{array}$ & $\begin{array}{l}\text { Blood } \\
\text { transfusion }\end{array}$ & $\begin{array}{l}\text { Use of } \\
\text { Tranexamic } \\
\text { acid as a } \\
\text { replacement } \\
\text { for blood } \\
\text { transfusion }\end{array}$ & Modelling & $\begin{array}{l}\text { Economic } \\
\text { evaluation }\end{array}$ & National & $\begin{array}{l}\text { Not } \\
\text { specified }\end{array}$ & Not specified & Literature \\
\hline $\begin{array}{l}\text { Kimaro et al } \\
2017\end{array}$ & Advanced HIV & $\begin{array}{l}\text { Providing } \\
\text { antiretroviral } \\
\text { therapy } \\
\text { services to } \\
\text { HIV-infected } \\
\text { individuals } \\
\text { presenting } \\
\text { with advanced } \\
\text { HIV disease }\end{array}$ & Cohort & $\begin{array}{l}\text { Economic } \\
\text { evaluation }\end{array}$ & $\begin{array}{l}\text { Dar es } \\
\text { Salaam }\end{array}$ & Public & $\begin{array}{l}\text { Primary health } \\
\text { center }\end{array}$ & $\begin{array}{l}\text { Patient } \\
\text { survey, health } \\
\text { care worker } \\
\text { diaries }\end{array}$ \\
\hline $\begin{array}{l}\text { Phillips et al } \\
2015\end{array}$ & Malaria & $\begin{array}{l}\text { Malaria Rapid } \\
\text { Diagnostic } \\
\text { test (mRDT) }\end{array}$ & Modelling & $\begin{array}{l}\text { Economic } \\
\text { evaluation }\end{array}$ & National & All & All & $\begin{array}{l}\text { Local } \\
\text { program/ } \\
\text { records }\end{array}$ \\
\hline $\begin{array}{l}\text { Shayo et al } \\
2017\end{array}$ & Tuberculosis & $\begin{array}{l}\text { Isoniazid } \\
\text { preventive } \\
\text { therapy }\end{array}$ & Cohort & $\begin{array}{l}\text { Economic } \\
\text { evaluation }\end{array}$ & $\begin{array}{l}\text { Dar es } \\
\text { Salaam }\end{array}$ & $\begin{array}{l}\text { NGO, } \\
\text { Public } \\
\text { and } \\
\text { private }\end{array}$ & $\begin{array}{l}\text { Tertiary and } \\
\text { primary care }\end{array}$ & $\begin{array}{l}\text { Records and } \\
\text { interviews }\end{array}$ \\
\hline
\end{tabular}




\begin{tabular}{|c|c|c|c|c|c|c|c|c|}
\hline Article & Disease area & Intervention & Study Type & Purpose Type & $\begin{array}{l}\text { Geographical } \\
\text { area covered }\end{array}$ & $\begin{array}{l}\text { Hospital } \\
\text { Type }\end{array}$ & $\begin{array}{l}\text { Facility/hospital } \\
\text { Level }\end{array}$ & $\begin{array}{l}\text { Source of } \\
\text { data }\end{array}$ \\
\hline $\begin{array}{l}\text { Wilson et al } \\
2020\end{array}$ & Neonatal care & $\begin{array}{l}\text { Birth } \\
\text { attendants } \\
\text { training on } \\
\text { neonatal } \\
\text { resuscitation } \\
\text { (59 } \\
\text { participants) }\end{array}$ & $\begin{array}{l}\text { Cross } \\
\text { sectional }\end{array}$ & $\begin{array}{l}\text { Financial } \\
\text { planning }\end{array}$ & Zanzibar & $\begin{array}{l}\text { Not } \\
\text { specified }\end{array}$ & Not specified & Survey \\
\hline
\end{tabular}

\section{Studies reporting on forms and resource availability in critical care}

\begin{tabular}{|c|c|c|c|c|c|c|c|c|}
\hline $\begin{array}{l}\text { Baker et al } \\
2011\end{array}$ & Critical care & $\begin{array}{l}\text { Emergency } \\
\text { and critical } \\
\text { care }\end{array}$ & $\begin{array}{l}\text { Cross } \\
\text { sectional }\end{array}$ & $\begin{array}{l}\text { Others } \\
\text { (structure and } \\
\text { resources } \\
\text { available for } \\
\text { emergency } \\
\text { and critical } \\
\text { care) }\end{array}$ & National & All & $\begin{array}{l}\text { Tertiary, district, } \\
\text { and primary } \\
\text { care }\end{array}$ & Survey \\
\hline $\begin{array}{l}\text { Chalya et al } \\
2011\end{array}$ & Trauma & Trauma care & $\begin{array}{l}\text { Cross } \\
\text { sectional }\end{array}$ & $\begin{array}{l}\text { Others } \\
\text { (describe } \\
\text { patient } \\
\text { characteristics } \\
\text { and health } \\
\text { outcomes) }\end{array}$ & Mwanza & NGO & $\begin{array}{l}\text { Referral } \\
\text { hospital }\end{array}$ & Survey \\
\hline $\begin{array}{l}\text { Mkoka et al } \\
2014\end{array}$ & Obstetrics & $\begin{array}{l}\text { Emergency } \\
\text { obstetric care }\end{array}$ & $\begin{array}{l}\text { Cross } \\
\text { sectional }\end{array}$ & $\begin{array}{l}\text { Others } \\
\text { (availability of } \\
\text { medical } \\
\text { supplies) }\end{array}$ & Kongwa & Public & $\begin{array}{l}\text { Primary } \\
\text { healthcare }\end{array}$ & Interviews \\
\hline $\begin{array}{l}\text { Mtango et al } \\
2019\end{array}$ & Critical care & Critical care & $\begin{array}{l}\text { Cross } \\
\text { sectional }\end{array}$ & $\begin{array}{l}\text { Others } \\
\text { (doctors' } \\
\text { experiences of } \\
\text { ICU referral) }\end{array}$ & $\begin{array}{l}\text { Dar es } \\
\text { salaam }\end{array}$ & Public & Tertiary referral & Interviews \\
\hline $\begin{array}{l}\text { Murthy et al } \\
2015\end{array}$ & Critical care & $\mathrm{N} / \mathrm{A}$ & Review & $\begin{array}{l}\text { Others } \\
\text { (estimate the } \\
\text { current ICU } \\
\text { capacity) }\end{array}$ & $\begin{array}{l}\text { Ifakara, Dar } \\
\text { es Salaam } \\
\text { and Mwanza }\end{array}$ & $\begin{array}{l}\text { NGO \& } \\
\text { Public }\end{array}$ & Tertiary referral & Literature \\
\hline $\begin{array}{l}\text { Mwandri et al } \\
2020\end{array}$ & Trauma & $\begin{array}{l}\text { Baseline } \\
\text { assessment of } \\
\text { trauma care } \\
\text { provision }\end{array}$ & $\begin{array}{l}\text { Cross } \\
\text { sectional }\end{array}$ & $\begin{array}{l}\text { Others } \\
\text { (assessing } \\
\text { burden and } \\
\text { care process) }\end{array}$ & $\begin{array}{l}\text { Mbeya and } \\
\text { Dar es } \\
\text { Salaam }\end{array}$ & $\begin{array}{l}\text { NGO \& } \\
\text { Public }\end{array}$ & Tertiary referral & $\begin{array}{l}\text { Hospital } \\
\text { registry data }\end{array}$ \\
\hline $\begin{array}{l}\text { Mwiga \& } \\
\text { Monaghan } \\
2020\end{array}$ & $\begin{array}{l}\text { Respiratory } \\
\text { illness }\end{array}$ & $\begin{array}{l}\text { Difficult } \\
\text { airway trolley }\end{array}$ & Case study & $\begin{array}{l}\text { Others } \\
\text { (development } \\
\text { of difficulty } \\
\text { airway trolley) }\end{array}$ & Mbeya & NGO & Tertiary referral & $\begin{array}{l}\text { Difficult } \\
\text { airway trolley }\end{array}$ \\
\hline $\begin{array}{l}\text { Nicks et al } \\
2012\end{array}$ & $\begin{array}{l}\text { Emergence } \\
\text { medicine }\end{array}$ & $\mathrm{N} / \mathrm{A}$ & Case study & $\begin{array}{l}\text { Others } \\
\text { (structure of } \\
\text { health system } \\
\text { and care } \\
\text { processes) }\end{array}$ & National & All & All & Literature \\
\hline $\begin{array}{l}\text { Papali et al } \\
2019\end{array}$ & Critical care & $\mathrm{N} / \mathrm{A}$ & Review & $\begin{array}{l}\text { Others } \\
\text { (structure and } \\
\text { organisation } \\
\text { of adult ICU) }\end{array}$ & $\mathrm{N} / \mathrm{A}$ & All & All & Literature \\
\hline $\begin{array}{l}\text { Penoyar et al } \\
2012\end{array}$ & Surgery & Surgical care & $\begin{array}{l}\text { Cross } \\
\text { sectional }\end{array}$ & $\begin{array}{l}\text { Others } \\
\text { (capacity of } \\
\text { first referral } \\
\text { hospitals) }\end{array}$ & National & All & $\begin{array}{l}\text { District, regional } \\
\text { and referral }\end{array}$ & Survey \\
\hline $\begin{array}{l}\text { Rajaguru et al } \\
2019\end{array}$ & Surgery & Surgery & $\begin{array}{l}\text { Cross } \\
\text { sectional }\end{array}$ & $\begin{array}{l}\text { Others } \\
\text { (operation and } \\
\text { financing of a } \\
\text { referral } \\
\text { hospital) }\end{array}$ & Mbeya & NGO & Tertiary referral & $\begin{array}{l}\text { Record } \\
\text { review }\end{array}$ \\
\hline $\begin{array}{l}\text { Reynolds et al } \\
2012\end{array}$ & $\begin{array}{l}\text { General } \\
\text { (particular } \\
\text { injuries, } \\
\text { pneumonia } \\
\text { and } \\
\text { psychosis) }\end{array}$ & $\begin{array}{l}\text { Emergency } \\
\text { care }\end{array}$ & $\begin{array}{l}\text { Cross } \\
\text { sectional }\end{array}$ & $\begin{array}{l}\text { Others } \\
\text { (Barriers to } \\
\text { emergency } \\
\text { care) }\end{array}$ & National & Public & Tertiary referral & Interview \\
\hline
\end{tabular}




\begin{tabular}{|c|c|c|c|c|c|c|c|c|}
\hline Article & Disease area & Intervention & Study Type & Purpose Type & $\begin{array}{l}\text { Geographical } \\
\text { area covered }\end{array}$ & $\begin{array}{l}\text { Hospital } \\
\text { Type }\end{array}$ & $\begin{array}{l}\text { Facility/hospital } \\
\text { Level }\end{array}$ & $\begin{array}{l}\text { Source of } \\
\text { data }\end{array}$ \\
\hline Sawe et 2016 & General & $\begin{array}{l}\text { Emergency } \\
\text { treatment }\end{array}$ & $\begin{array}{l}\text { Cross } \\
\text { sectional }\end{array}$ & $\begin{array}{l}\text { Others } \\
\text { (clinical } \\
\text { presentation } \\
\text { and resource } \\
\text { utilization) }\end{array}$ & $\begin{array}{l}\text { Dar es } \\
\text { Salaam }\end{array}$ & Public & Tertiary referral & $\begin{array}{l}\text { Hospital } \\
\text { record }\end{array}$ \\
\hline $\begin{array}{l}\text { Staton et al } \\
2017\end{array}$ & $\begin{array}{l}\text { Traumatic } \\
\text { Brain Injury }\end{array}$ & Trauma care & $\begin{array}{l}\text { Cross } \\
\text { sectional }\end{array}$ & $\begin{array}{l}\text { Others } \\
\text { (describe } \\
\text { quality of care } \\
\text { for TBI) }\end{array}$ & Kilimanjaro & NGO & $\begin{array}{l}\text { Referral } \\
\text { Hospital }\end{array}$ & Survey \\
\hline $\begin{array}{l}\text { Sylvanus et al } \\
2019\end{array}$ & Renal failure & $\begin{array}{l}\text { Renal failure } \\
\text { treatment and } \\
\text { management }\end{array}$ & Cohort & $\begin{array}{l}\text { Others (renal } \\
\text { failure case } \\
\text { management) }\end{array}$ & $\begin{array}{l}\text { Dar es } \\
\text { Salaam }\end{array}$ & Public & Tertiary referral & Survey \\
\hline $\begin{array}{l}\text { Zimmerman et } \\
\text { al } 2020\end{array}$ & $\begin{array}{l}\text { Acute } \\
\text { traumatic } \\
\text { brain injury }\end{array}$ & $\begin{array}{l}\text { Quantifying } \\
\text { the effect on } \\
\text { outcomes } \\
\text { from delays in } \\
\text { the care of } \\
\text { trauma }\end{array}$ & $\begin{array}{l}\text { Cross } \\
\text { sectional }\end{array}$ & $\begin{array}{l}\text { Others } \\
\text { (association } \\
\text { of hospital } \\
\text { delays and } \\
\text { poor } \\
\text { outcomes) }\end{array}$ & Moshi & NGO & Tertiary referral & Hospital data \\
\hline
\end{tabular}

Note: Others (under purpose type) includes studies that do not report costs. Interviews in this table mean that the study used in-depth interviews to collect data.

Table 3: Types of costs reported and sources of data

\begin{tabular}{|c|c|c|c|c|c|}
\hline Study & $\begin{array}{l}\text { Economic/financial } \\
\text { cost/both }\end{array}$ & $\begin{array}{l}\text { Real world } \\
\text { /guideline cost }\end{array}$ & $\begin{array}{l}\text { Full/incremental } \\
\text { cost }\end{array}$ & $\begin{array}{l}\text { Top down/ bottom up } \\
\text { estimations/both }\end{array}$ & Source of cost data \\
\hline $\begin{array}{l}\text { Githang'a et } \\
2020\end{array}$ & Financial & $\begin{array}{l}\text { Real world } \\
\text { costs }\end{array}$ & Full costs & Both & Hospital data \\
\hline $\begin{array}{l}\text { Mengistu et al } \\
2019\end{array}$ & Financial & $\begin{array}{l}\text { Real world } \\
\text { costs }\end{array}$ & Full costs & Top-down estimation & $\begin{array}{l}\text { Programme, hospital and health center } \\
\text { data }\end{array}$ \\
\hline $\begin{array}{l}\text { Wilson et al } \\
2020\end{array}$ & Financial & $\begin{array}{l}\text { Real world } \\
\text { costs }\end{array}$ & Full costs & Bottom-up estimation & Staff Survey $(\mathrm{N}=59)$ \\
\hline $\begin{array}{l}\text { Kimaro et al } \\
2017\end{array}$ & Economic costs & $\begin{array}{l}\text { Real world } \\
\text { costs }\end{array}$ & Full costs & Bottom-up estimation & Patient survey, diaries $(\mathrm{N}=870)$ \\
\hline $\begin{array}{l}\text { Shayo et al } \\
2017\end{array}$ & Economic costs & $\begin{array}{l}\text { Real world } \\
\text { costs }\end{array}$ & Full costs & Bottom-up estimation & $\begin{array}{l}\text { Records, government standards and } \\
\text { market price survey }\end{array}$ \\
\hline $\begin{array}{l}\text { Phillips et al } \\
2015\end{array}$ & Economic costs & $\begin{array}{l}\text { Real world } \\
\text { costs }\end{array}$ & Full costs & Top down estimation & Local program records \\
\hline $\begin{array}{l}\text { Penno et al } \\
2015\end{array}$ & Economic costs & $\begin{array}{l}\text { Real world } \\
\text { costs }\end{array}$ & Full costs & Bottom-up estimation & Laboratory records \\
\hline $\begin{array}{l}\text { Kabadi et al } \\
2013\end{array}$ & Economic costs & $\begin{array}{l}\text { Real world } \\
\text { costs }\end{array}$ & Full costs & Bottom-up estimation & Survey $(\mathrm{N}=16)$ and project data \\
\hline $\begin{array}{l}\text { Sicuri et al } \\
2011\end{array}$ & Economic costs & $\begin{array}{l}\text { Real world } \\
\text { costs }\end{array}$ & Full costs & Bottom-up estimation & Patient Survey $(\mathrm{N}=150)$ \\
\hline $\begin{array}{l}\text { Guerriero et al } \\
2010\end{array}$ & Economic costs & $\begin{array}{l}\text { Real world } \\
\text { costs }\end{array}$ & Full costs & $\mathrm{N} / \mathrm{A}$ & Literature \\
\hline $\begin{array}{l}\text { Baynes et al } \\
2019\end{array}$ & Financial costs & $\begin{array}{l}\text { Real world } \\
\text { costs }\end{array}$ & Full costs & Bottom-up estimation & $\begin{array}{l}\text { Health facility Records }(\mathrm{N}=31) \text { and key } \\
\text { informant interviews }(\mathrm{N}=124)\end{array}$ \\
\hline $\begin{array}{l}\text { Riewpaiboon } \\
\text { et al } 2014\end{array}$ & Economic costs & $\begin{array}{l}\text { Real world } \\
\text { costs }\end{array}$ & Full costs & Bottom-up estimation & Record review and patient survey $(\mathrm{N}=17)$ \\
\hline $\begin{array}{l}\text { Sumona et al } \\
2016\end{array}$ & Financial costs & $\begin{array}{l}\text { Real world } \\
\text { costs }\end{array}$ & Full costs & Bottom-up estimation & Health facility Survey $(\mathrm{N}=386)$ \\
\hline $\begin{array}{l}\text { Chris et al } \\
2013\end{array}$ & Financial costs & $\begin{array}{l}\text { Real world } \\
\text { costs }\end{array}$ & Full costs & Top-down estimation & Facility Survey $(\mathrm{N}=155)$ \\
\hline
\end{tabular}




\begin{tabular}{|c|c|c|c|c|c|}
\hline Study & Description & $\begin{array}{l}\text { Unit cost of } \\
\text { output }\end{array}$ & $\begin{array}{l}\text { Currency } \\
\text { year }\end{array}$ & $\begin{array}{l}\text { Unit cost Price in } \\
2019 \text { (USD) }\end{array}$ & $\begin{array}{l}\text { Unit cost Price in } \\
2019 \text { (TZS) }\end{array}$ \\
\hline $\begin{array}{l}\text { Mengistu et al } \\
2019\end{array}$ & Clinical care for emergency obstetric case & per case & 2013 & 143.85 & 329,166 . \\
\hline $\begin{array}{l}\text { Mengistu et al } \\
2019\end{array}$ & Average cost per surgical patient & per patient & 2013 & 285.08 & $652,333.26$ \\
\hline $\begin{array}{l}\text { Mengistu et al } \\
2019\end{array}$ & Average cost per patient undergoing caesarean & Per patient & 2013 & 471.28 & $1,078,396.41$ \\
\hline $\begin{array}{l}\text { Riewpaiboon et al } \\
2014\end{array}$ & Inpatient hospital cost & $\begin{array}{l}\text { Per patient } \\
\text { per day }\end{array}$ & 2010 & 91.78 & 107.49 \\
\hline Sicuri et al 2011 & $\begin{array}{l}\text { Episode of Malaria hospitalisation and Severe } \\
\text { anaemia }\end{array}$ & per episode & 2009 & 57.12 & $130,704.61$ \\
\hline Sicuri et al 2011 & Episode of Cerebral malaria & per episode & 2009 & 22.67 & $51,864.33$ \\
\hline Sicuri et al 2011 & Episode of Cerebral malaria and neurological sequela & per episode & 2009 & 47.58 & $108,879.84$ \\
\hline Kabadi et al 2013 & $\begin{array}{l}\text { Hospitalisation of stroke patient (Inpatient, Drugs, } \\
\text { Registration)- Rural area }\end{array}$ & per patient & $\begin{array}{l}2005- \\
2006\end{array}$ & 12.76 & $29,200.18$ \\
\hline Kabadi et al 2013 & $\begin{array}{l}\text { Hospitalisation of stroke patient (Inpatient, Drugs, } \\
\text { Registration)- Urban area }\end{array}$ & per patient & $\begin{array}{l}2005- \\
2006\end{array}$ & 31.17 & $71,317.89$ \\
\hline Kabadi et al 2013 & Physiotherapy for stroke- urban area & per patient & $\begin{array}{l}2005- \\
2006\end{array}$ & 44.88 & $102,697.20$ \\
\hline Kabadi et al 2013 & $\begin{array}{l}\text { Hospitalisation of stroke patient (Inpatient, Drugs, } \\
\text { Registration)- average }\end{array}$ & per patient & $\begin{array}{l}2005- \\
2006\end{array}$ & 18.51 & $42,361.25$ \\
\hline Kabadi et al 2013 & Physiotherapy for stroke- average & per patient & $\begin{array}{l}2005- \\
2006\end{array}$ & 14.03 & $32,093.43$ \\
\hline $\begin{array}{l}\text { James, Bura \& } \\
\text { Ensor } 2013\end{array}$ & Health centre: overall & $\begin{array}{l}\text { Inpatient } \\
\text { day }\end{array}$ & $2011 / 12$ & 18.03 & $41,261.22$ \\
\hline $\begin{array}{l}\text { James, Bura \& } \\
\text { Ensor } 2013\end{array}$ & Health centre: public & $\begin{array}{l}\text { Inpatient } \\
\text { day }\end{array}$ & $2011 / 12$ & 18.98 & $43,432.74$ \\
\hline $\begin{array}{l}\text { James, Bura \& } \\
\text { Ensor } 2013\end{array}$ & health centre: NGO & $\begin{array}{l}\text { Inpatient } \\
\text { day }\end{array}$ & $2011 / 12$ & 17.29 & $39,564.68$ \\
\hline $\begin{array}{l}\text { James, Bura \& } \\
\text { Ensor } 2013\end{array}$ & Hospital: all & $\begin{array}{l}\text { Inpatient } \\
\text { day }\end{array}$ & $2011 / 12$ & 25.95 & $59,387.93$ \\
\hline $\begin{array}{l}\text { James, Bura \& } \\
\text { Ensor } 2013\end{array}$ & Hospital: public & $\begin{array}{l}\text { Inpatient } \\
\text { day }\end{array}$ & $2011 / 12$ & 18.54 & $42,422.55$ \\
\hline $\begin{array}{l}\text { James, Bura \& } \\
\text { Ensor } 2013\end{array}$ & Hospital: NGO & $\begin{array}{l}\text { Inpatient } \\
\text { day }\end{array}$ & $2011 / 12$ & 15.76 & $36,062.52$ \\
\hline $\begin{array}{l}\text { James, Bura \& } \\
\text { Ensor } 2013\end{array}$ & Hospital: private & $\begin{array}{l}\text { Inpatient } \\
\text { day }\end{array}$ & $2011 / 12$ & 68.05 & $155,721.31$ \\
\hline $\begin{array}{l}\text { James, Bura \& } \\
\text { Ensor } 2013\end{array}$ & Hospital regional & $\begin{array}{l}\text { Inpatient } \\
\text { day }\end{array}$ & $2011 / 12$ & 17.33 & $39,653.32$ \\
\hline $\begin{array}{l}\text { James, Bura \& } \\
\text { Ensor } 2013\end{array}$ & Hospital - ARI-pneumonia & $\begin{array}{l}\text { per case } \\
\text { treated }\end{array}$ & $2011 / 12$ & 104.33 & $238,736.91$ \\
\hline $\begin{array}{l}\text { James, Bura \& } \\
\text { Ensor } 2013\end{array}$ & Hospital - Hypertension & $\begin{array}{l}\text { per case } \\
\text { treated }\end{array}$ & $2011 / 12$ & 253.98 & $581,166.07$ \\
\hline $\begin{array}{l}\text { James, Bura \& } \\
\text { Ensor } 2013\end{array}$ & Hospital - Myocardial infarction & $\begin{array}{l}\text { per case } \\
\text { treated }\end{array}$ & $2011 / 12$ & 268.57 & $614,533.21$ \\
\hline
\end{tabular}

Table 5: Cost of Equipment, consumables, and medication 


\begin{tabular}{|c|c|c|c|c|c|}
\hline Study & Description & $\begin{array}{l}\text { Unit cost } \\
\text { of output }\end{array}$ & $\begin{array}{l}\text { Currency } \\
\text { year }\end{array}$ & $\begin{array}{l}\text { Unit cost Price } \\
\text { in } 2019 \text { (USD) }\end{array}$ & $\begin{array}{l}\text { Unit cost Price } \\
\text { in } 2019 \text { (TZS) }\end{array}$ \\
\hline \multicolumn{6}{|l|}{ Equipment } \\
\hline $\begin{array}{l}\text { Chaudhury et al } \\
2016\end{array}$ & Mannequin & per piece & 2014 & 76.03 & $173,970.65$ \\
\hline $\begin{array}{l}\text { Chaudhury et al } \\
2016\end{array}$ & Bag-mask device & per piece & 2014 & 16.29 & $37,279.43$ \\
\hline $\begin{array}{l}\text { Chaudhury et al } \\
2016\end{array}$ & Penguin sucke & per piece & 2014 & 3.26 & $7,455.89$ \\
\hline $\begin{array}{l}\text { Mengistu et al } \\
2019\end{array}$ & Equipment needed for emergency obstetric care & $\begin{array}{l}\text { per } \\
\text { patient }\end{array}$ & 2013 & 90.02 & $205,994.65$ \\
\hline \multicolumn{6}{|l|}{ Consumables } \\
\hline $\begin{array}{l}\text { Mengistu et al } \\
2019\end{array}$ & Other supplies for emergency obstetric care & $\begin{array}{l}\text { per } \\
\text { patient }\end{array}$ & 2013 & 28.68 & $65,635.80$ \\
\hline $\begin{array}{l}\text { Mengistu et al } \\
2019\end{array}$ & Blood supplies & $\begin{array}{l}\text { per } \\
\text { patient }\end{array}$ & 2013 & 0.71 & $1,620.01$ \\
\hline $\begin{array}{l}\text { Guerriero et al } \\
2010\end{array}$ & $\begin{array}{l}\text { Consumables needed in the administration of tranexamic acid } \\
(10 \mathrm{ml} \text { syringe, } 100 \mathrm{ml} \text { bag of saline, large gauge needle) }\end{array}$ & Per dose & 2007 & 2.00 & $4,576.41$ \\
\hline \multicolumn{6}{|l|}{ Medication } \\
\hline \multicolumn{6}{|l|}{$\begin{array}{l}\text { Analgesics and } \\
\text { sedatives }\end{array}$} \\
\hline $\begin{array}{l}\text { Riewpaiboon et al } \\
2014\end{array}$ & Paracetamol $120 \mathrm{mg} / 5 \mathrm{~mL}$ in $60-\mathrm{mL}$ bottle & per bottle & 2010 & 0.33 & 750.38 \\
\hline $\begin{array}{l}\text { Riewpaiboon et al } \\
2014\end{array}$ & Paracetamol $500 \mathrm{mg}$ tablet & Per tablet & 2010 & 0.01 & 26.80 \\
\hline \multicolumn{6}{|l|}{$\begin{array}{l}\text { Antifungal and } \\
\text { antibacterial } \\
\text { drugs }\end{array}$} \\
\hline $\begin{array}{l}\text { Riewpaiboon et al } \\
2014\end{array}$ & Ampicillin 500 mg vial injection & Per piece & 2010 & 0.21 & 482.39 \\
\hline $\begin{array}{l}\text { Riewpaiboon et al } \\
2014\end{array}$ & Ceftriaxone $250 \mathrm{mg}$ vial injection & Per piece & 2010 & 0.46 & $1,045.17$ \\
\hline $\begin{array}{l}\text { Riewpaiboon et al } \\
2014\end{array}$ & Ciprofloxacin 250 mg capsule & $\begin{array}{l}\text { Per } \\
\text { Capsule }\end{array}$ & 2010 & 0.01 & 26.80 \\
\hline $\begin{array}{l}\text { Riewpaiboon et al } \\
2014\end{array}$ & Ciprofloxacin 500 mg capsule & $\begin{array}{l}\text { Per } \\
\text { capsule }\end{array}$ & 2010 & 0.05 & 107.20 \\
\hline Penno et al 2015 & $\begin{array}{l}\text { Antimicrobial treatment using generic drugs for sepsis } \\
\text { management }\end{array}$ & per case & 2011 & 15.17 & $34,703.66$ \\
\hline Penno et al 2015 & Evidence-based antimicrobials & Per case & 2011 & 30.36 & $69,459.83$ \\
\hline Kimaro et al 2017 & Cotrimoxazole per daily dose & $\begin{array}{l}\text { Per daily } \\
\text { dose }\end{array}$ & 2012 & 0.02 & 51.51 \\
\hline \multicolumn{6}{|l|}{$\begin{array}{l}\text { Others like anti- } \\
\text { cancers }\end{array}$} \\
\hline $\begin{array}{l}\text { Githang'a et al } \\
2020\end{array}$ & 50 mg of 6-mercaptopurine (6MP) & Unclear & 2013 & 0.39 & 885.94 \\
\hline $\begin{array}{l}\text { Mengistu et al } \\
2019\end{array}$ & Drugs for emergency obstetric care & $\begin{array}{l}\text { per } \\
\text { patient }\end{array}$ & 2013 & 6.90 & $15,795.12$ \\
\hline $\begin{array}{l}\text { Riewpaiboon et al } \\
2014\end{array}$ & Glucose (5\%) $500 \mathrm{~mL}$ & Per unit & 2010 & 0.50 & $1,152.37$ \\
\hline $\begin{array}{l}\text { Guerriero et al } \\
2010\end{array}$ & Tranexamic acid & Per dose & 2007 & 9.74 & $22,279.66$ \\
\hline
\end{tabular}

Note: No cardiovascular drugs and anticonvulsant drugs were reported in included studies.

Table 6: Cost of human resources 


\begin{tabular}{|c|c|c|c|c|c|}
\hline Study & Description & $\begin{array}{l}\text { Unit of } \\
\text { output }\end{array}$ & $\begin{array}{l}\text { Currency } \\
\text { year }\end{array}$ & $\begin{array}{l}\text { Unit cost Price in } \\
2019 \text { (USD) }\end{array}$ & $\begin{array}{l}\text { Unit cost Price in } \\
2019 \text { (TZS) }\end{array}$ \\
\hline $\begin{array}{l}\text { Mengistu et } \\
\text { al } 2019\end{array}$ & Total personnel for Emergency obstetric care & $\begin{array}{l}\text { per } \\
\text { patient }\end{array}$ & 2013 & 103.01 & $235,711.74$ \\
\hline $\begin{array}{l}\text { Baynes et al } \\
2019\end{array}$ & Cost of Obstetrician/gynecologist on all complications & $\begin{array}{l}\text { Per } \\
\text { patient }\end{array}$ & 2016 & 10.00 & $22,884.06$ \\
\hline $\begin{array}{l}\text { Baynes et al } \\
2019\end{array}$ & Cost of Anesthesiologist on all obstetric complications & $\begin{array}{l}\text { Per } \\
\text { patient }\end{array}$ & 2016 & 0.00 & 0.00 \\
\hline $\begin{array}{l}\text { Baynes et al } \\
2019\end{array}$ & Cost Anesthetist on all obstetric complications & $\begin{array}{l}\text { Per } \\
\text { patient }\end{array}$ & 2016 & 2.23 & $5,112.40$ \\
\hline $\begin{array}{l}\text { Baynes et al } \\
2019\end{array}$ & $\begin{array}{l}\text { Cost of Anesthetist Assistant on all obstetric } \\
\text { complications }\end{array}$ & $\begin{array}{l}\text { Per } \\
\text { patient }\end{array}$ & 2016 & 1.81 & $4,138.61$ \\
\hline $\begin{array}{l}\text { Baynes et al } \\
2019\end{array}$ & $\begin{array}{l}\text { Cost of doctor/ medical officer on all obstetric } \\
\text { complications }\end{array}$ & $\begin{array}{l}\text { Per } \\
\text { patient }\end{array}$ & 2016 & 15.75 & $36,030.22$ \\
\hline $\begin{array}{l}\text { Baynes et al } \\
2019\end{array}$ & $\begin{array}{l}\text { Cost of assistant medical officer on all obstetric } \\
\text { complications }\end{array}$ & $\begin{array}{l}\text { Per } \\
\text { patient }\end{array}$ & 2016 & 5.00 & $11,442.03$ \\
\hline $\begin{array}{l}\text { Baynes et al } \\
2019\end{array}$ & Cost of clinical officer on all obstetric complications & $\begin{array}{l}\text { Per } \\
\text { patient }\end{array}$ & 2016 & 0.85 & $1,947.58$ \\
\hline $\begin{array}{l}\text { Baynes et al } \\
2019\end{array}$ & $\begin{array}{l}\text { Cost of registered nurse or principal enrolled nurse on } \\
\text { obstetric all complications }\end{array}$ & $\begin{array}{l}\text { Per } \\
\text { patient }\end{array}$ & 2016 & 9.79 & $22,397.16$ \\
\hline $\begin{array}{l}\text { Baynes et al } \\
2019\end{array}$ & $\begin{array}{l}\text { Cost of enrolled nurse or midwife on all obstetric } \\
\text { complications }\end{array}$ & $\begin{array}{l}\text { Per } \\
\text { patient }\end{array}$ & 2016 & 43.62 & $99,813.44$ \\
\hline $\begin{array}{l}\text { Baynes et al } \\
2019\end{array}$ & Cost of medical attendant on all obstetric complications & $\begin{array}{l}\text { Per } \\
\text { patient }\end{array}$ & 2016 & 6.06 & $13,876.50$ \\
\hline $\begin{array}{l}\text { Baynes et al } \\
2019\end{array}$ & Cost of laboratory technician on all complications & $\begin{array}{l}\text { Per } \\
\text { patient }\end{array}$ & 2016 & 3.19 & $7,303.42$ \\
\hline $\begin{array}{l}\text { Baynes et al } \\
2019\end{array}$ & Cost of laboratory assistant on all complications & $\begin{array}{l}\text { Per } \\
\text { patient }\end{array}$ & 2016 & 1.70 & $3,895.16$ \\
\hline $\begin{array}{l}\text { Baynes et al } \\
2019\end{array}$ & Cost of Sonographer on all obstetric complications & $\begin{array}{l}\text { Per } \\
\text { patient }\end{array}$ & 2016 & 2.87 & $6,573.08$ \\
\hline $\begin{array}{l}\text { Baynes et al } \\
2019\end{array}$ & Cost of pharmacist on all complications & $\begin{array}{l}\text { Per } \\
\text { patient }\end{array}$ & 2016 & 2.55 & $5,842.74$ \\
\hline $\begin{array}{l}\text { Baynes et al } \\
2019\end{array}$ & Cost of drug dispenser on all complications & $\begin{array}{l}\text { Per } \\
\text { patient }\end{array}$ & 2016 & 1.06 & $2,434.47$ \\
\hline $\begin{array}{l}\text { Baynes et al } \\
2019\end{array}$ & $\begin{array}{l}\text { Average personnel costs at primary care level facilities for } \\
\text { all complications }\end{array}$ & $\begin{array}{l}\text { Per } \\
\text { patient }\end{array}$ & 2016 & 14.28 & $32,670.64$ \\
\hline $\begin{array}{l}\text { Baynes et al } \\
2019\end{array}$ & $\begin{array}{l}\text { Average personnel care costs at district hospitals for all } \\
\text { complications }\end{array}$ & $\begin{array}{l}\text { Per } \\
\text { patient }\end{array}$ & 2016 & 8.97 & $20,522.62$ \\
\hline $\begin{array}{l}\text { Baynes et al } \\
2019\end{array}$ & $\begin{array}{l}\text { Average personnel costs at Regional hospital for all } \\
\text { complications }\end{array}$ & $\begin{array}{l}\text { Per } \\
\text { patient }\end{array}$ & 2016 & 30.14 & $68,968.66$ \\
\hline $\begin{array}{l}\text { Baynes et al } \\
2019\end{array}$ & $\begin{array}{l}\text { Average personnel costs for all complications across any } \\
\text { level of hospital }\end{array}$ & $\begin{array}{l}\text { Per } \\
\text { patient }\end{array}$ & 2016 & 19.16 & $43,844.88$ \\
\hline $\begin{array}{l}\text { Shayo et al } \\
2017\end{array}$ & Assistant medical officer & $\begin{array}{l}\text { Monthly } \\
\text { salary }\end{array}$ & 2012 & 638.96 & $1,462,064.84$ \\
\hline $\begin{array}{l}\text { Shayo et al } \\
2017\end{array}$ & Nurse & $\begin{array}{l}\text { Monthly } \\
\text { salary }\end{array}$ & 2012 & 313.34 & $716,994.91$ \\
\hline $\begin{array}{l}\text { Shayo et al } \\
2017\end{array}$ & Health Attendant & $\begin{array}{l}\text { Monthly } \\
\text { salary }\end{array}$ & 2012 & 440.41 & $1,007,738.83$ \\
\hline $\begin{array}{l}\text { Shayo et al } \\
2017\end{array}$ & Assistant Nurse & $\begin{array}{l}\text { Monthly } \\
\text { salary }\end{array}$ & 2012 & 338.60 & $774,793.40$ \\
\hline $\begin{array}{l}\text { Shayo et al } \\
2017\end{array}$ & Nurse Counsellors & $\begin{array}{l}\text { Monthly } \\
\text { salary }\end{array}$ & 2012 & 819.44 & $1,875,051.02$ \\
\hline $\begin{array}{l}\text { Shayo et al } \\
2017\end{array}$ & Medical Doctors & $\begin{array}{l}\text { Monthly } \\
\text { salary }\end{array}$ & 2012 & 1473.56 & $3,371,810.40$ \\
\hline $\begin{array}{l}\text { Shayo et al } \\
2017\end{array}$ & Medical Specialists & $\begin{array}{l}\text { Monthly } \\
\text { salary }\end{array}$ & 2012 & 2721.79 & $6,228,019.13$ \\
\hline $\begin{array}{l}\text { Shayo et al } \\
2017\end{array}$ & Laboratory Scientific Officer & $\begin{array}{l}\text { Monthly } \\
\text { salary }\end{array}$ & 2012 & 1106.07 & $2,530,924.80$ \\
\hline
\end{tabular}




\begin{tabular}{|lllll|}
$\begin{array}{l}\text { Shayo et al } \\
2017\end{array}$ & Laboratory technician & $\begin{array}{l}\text { Monthly } \\
\text { salary }\end{array}$ & 2012 & 819.44 \\
\hline $\begin{array}{l}\text { Shayo et al } \\
2017\end{array}$ & Pharmacist & $\begin{array}{l}\text { Monthly } \\
\text { salary }\end{array}$ & 2012 & $1,875,051.02$ \\
\hline $\begin{array}{l}\text { Shayo et al } \\
2017\end{array}$ & Pharmacy technician & $\begin{array}{l}\text { Monthly } \\
\text { salary }\end{array}$ & 2012 & 819.44 \\
\hline
\end{tabular}

\section{Figures}

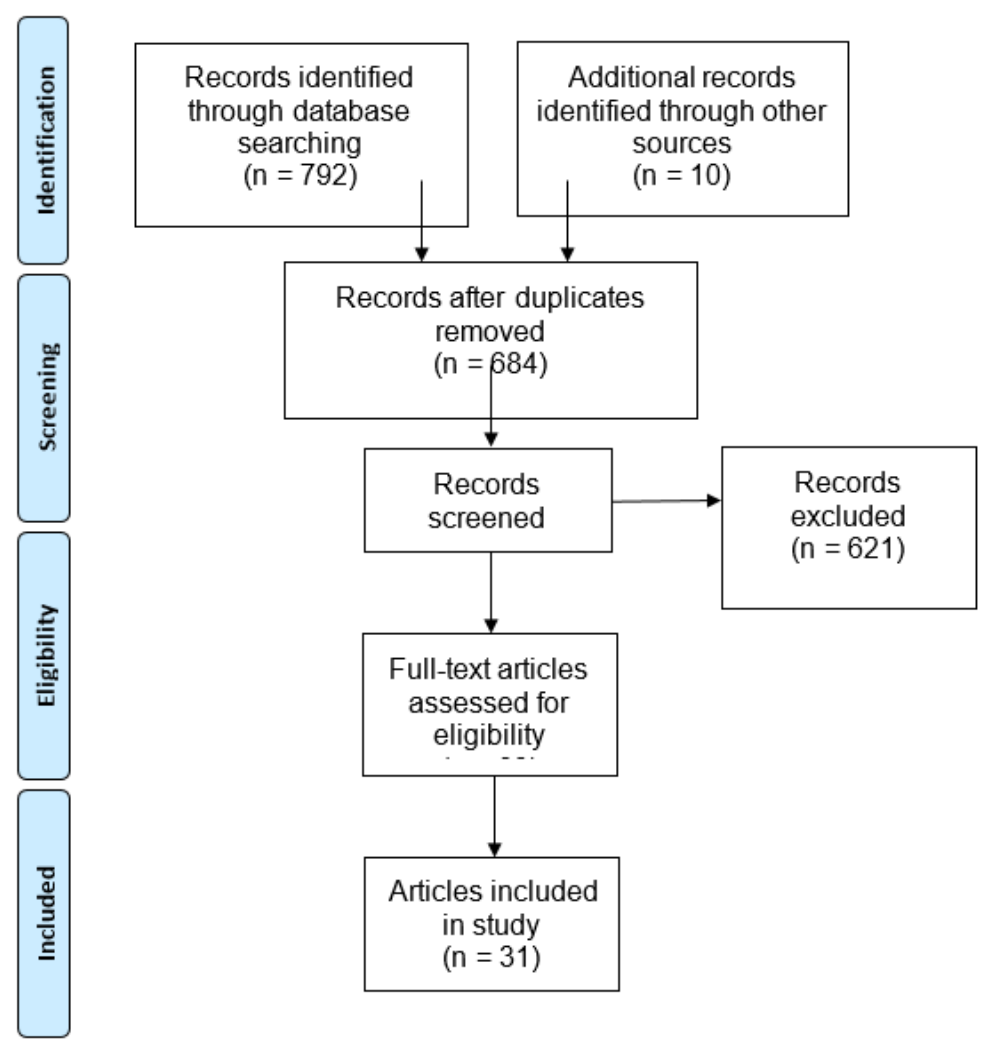

Figure 1

Flow diagram of the study selection process

\section{Supplementary Files}

This is a list of supplementary files associated with this preprint. Click to download.

- PRISMA2020checklist.docx

- Supplementary.docx 